\title{
Predictors of iron overload toxicity in multi-transfused beta-thalassemic children
}

\author{
Nihar Ranjan Mishra', Sumeet Soumyaranjan Biswal'², Subash Chandra Majhi ${ }^{3}$ \\ From ${ }^{1}$ Assistant Professor, ${ }^{2}$ Post Graduate Student, ${ }^{3}$ Associate Professor, Department of Pediatrics, Veer Surendra Sai Institute of Medical Science \\ and Research, Sambalpur, Odisha, India
}

Correspondence to: Dr. Sumeet Soumyaranjan Biswal, Department of Pediatrics, Veer Surendra Sai Institute of Medical Science and Research, Sambalpur, Odisha, India. E-mail: smtbswl111@gmail.com

Received - 24 March $2019 \quad$ Initial Review - 19 April 2019

Accepted - 06 June 2019

\begin{abstract}
Introduction: There are certain risk factors or predictors that can be used for early detection of cardiac iron overload to improve the long-term gains in beta-thalassemic children. Objective: The aim of the study was to consider the predictive abilities of some of the clinical attributes of the beta-thalassemia patients regarding cardiac iron overload to identify at risk patients. Materials and Methods: This current observational study was conducted in the Department of Pediatrics, VIMSAR, Burla from November 2016 to October 2018. A total of 105 thalassemic children were enrolled in the study after satisfying the inclusion criteria (multi-transfused beta-thalassemia children in the age group of 6-14 years). All the relevant data were collected and correlationregression statistics were done using computer-based software. Results: Serum ferritin has weak negative correlation with left ventricular end diastolic diameter (LVEDD) $(\mathrm{r}=0.511, \mathrm{p}=0.000)$, good negative correlation with ejection fraction $(\mathrm{EF})(\mathrm{r}=-0.604$, $\mathrm{p}=0.000$ ), and weak positive correlation with left ventricular end systolic diameter (LVESD) $(\mathrm{r}=0.084, \mathrm{p}=0.393)$. Number of units of packed red cell transfusion has strong negative correlation with $E F(r=0.785, p=0.000)$, weak negative correlation with LVEDD $(\mathrm{r}=0.297, \mathrm{p}=0.005)$, and weak positive correlation with LVESD $(\mathrm{r}=0.413, \mathrm{p}=0.000)$. Corrected logistic regression equation, i.e., cardiac iron overload $=1.997$ (age in years) -3.119 (gender) -0.078 (units of packed red blood cells [PRBC]) +0.003 (serum ferritin in $\mathrm{ng} / \mathrm{ml}$ ) -0.149 (LVEDD in $\mathrm{mm}$ ) -0.235 (weight in $\mathrm{kg}$ ) -10.928 with prediction of $94.3 \%$. Conclusions: Age of the patient, serum ferritin level, and number of units of PRBCs transfused, LVEDD and weight of the child are good predictors of myocardial iron overload among childhood beta-thalassemic and hence can be used as indices for monitoring of onset of cardiac iron overload.
\end{abstract}

Key words: Beta-thalassemia major, Ejection fraction, Iron overload, Left ventricular end-diastolic diameter, Left ventricular end-systolic diameter, Predictors, Serum ferritin level

$\mathrm{B}$ eta-thalassemia comprises the group of hereditary hemoglobinopathy characterized by pathological beta chains structures in hemoglobin leading to variable phenotypes from severe anemia to asymptomatic and apparently healthy subjects. Poorly managed cases in some developing countries manifest with growth retardation, pallor, jaundice, lean body, hepato-splenomegaly, leg ulcers, and extramedullary hematopoiesis, along with bony affections due to marrow expansion. Frequent packed red cell transfusion therapy results with iron overload-related complications such as endocrine complication (growth retardation, diabetes mellitus, insufficiency of the parathyroid, thyroid, etc.), dilated cardiomyopathy, and cirrhosis of the liver.

Cardiac failure following iron overload is the chief cause of death in children with beta-thalassemia major. Majority of the affected children suffer from myocardial fibrosis and the accompanying iron overload cardiomyopathy [1,2]. Chelation therapy diminishes cardiac iron overload and dwindles the rate of mortality in such patients. Cardiac involvement in iron overload cases includes chamber dilatation, valvular dysfunction, pericarditis, arrhythmias, and muscular hypertrophy resulting in cardiac failure $[2,3]$. Iron stores mainly exist in the body in the form of ferritin, a bit of which is secreted into the plasma. With no inflammation in place, the concentration of the serum ferritin correlates positively with the amount of the iron stores.

Normal serum ferritin concentration varies with age and sex. At birth, its high followed by an elevation in an initial couple of months of life, and thereafter falls by late infancy [4]. By the $1^{\text {st }}$ year, concentrations begin to rise again and continue to increase henceforth [5]. By adolescence, males have a higher concentration than the females, which continues into adulthood. It is also an acute-phase protein elevates significantly in numerously different other conditions and some studies report its poor correlation with myocardial iron load, though has got a linear correlation with the hepatic iron stores [6,7]. Still, concentration $>2500 \mathrm{ng} / \mathrm{mL}$ indicates dangerous total body iron content [8]. Such persistently elevated serum ferritin levels can assist in predicting a grave risk of cardiac involvement [9].

Serum ferritin levels can predictably ascertain cardiac iron overload when cardiac magnetic resonance imaging $\mathrm{T} 2 *$ is used 
as the gold standard $[10,11]$. Little is known about the natural history of iron deposition in the heart. In non-chelated patients receiving regular transfusions, cardiomegaly develops by the age of 10 years and heart failure by the age of 16 years [12]. Previous studies acknowledged that serum ferritin levels were higher in beta-thalassemia patients who had received more than 50 transfusions [11]. The objectives of our study were to assess the predictive abilities of some of the clinical attributes of the betathalassemia patients regarding cardiac iron overload to identify at-risk patients and hence using the knowledge to sensitize the clinician in screening the at-risk patients and hence, reducing the morbidity and mortality.

\section{MATERIALS AND METHODS}

This current observational analytical cross-sectional study was conducted in the Department of Paediatrics, VIMSAR, Burla; a tertiary care hospital situated in the Western part of Odisha after taking approval from the Institute's Ethical Committee. In previous studies, the correlation factor for ejection fraction (EF) with serum ferritin was noted to be $\mathrm{r}=0.3^{1}$ and as this is the most recent study as well as similar to our present study, we chose this the reference for calculating the sample size of our present study. Sample size was calculated by regression-correlation coefficient (testing for $r=0$ ) method with taking the reference coefficient factor as $r=0.3^{1}$, and power of the study to be $90 \%$ and $\alpha=5 \%$ and taking two-sided significance level, minimum sample size was calculated to be 104 using n master (v2, BRTC, Bagayam, Vellore).

A total of 115 cases were enrolled in the study as per the inclusion criteria which included multi-transfused [13] betathalassemic in the age group of 6-14 years and exclusion criteria which were to exclude the patients with any congenital heart diseases, rheumatic heart disease or any other structural heart defects and the associated comorbidities such as hypertension, dyselectrolytemia, hyperthyroidism, and type 1 diabetes mellitus. Out of 115 children, parents of 10 children did not give consent; so, 105 patients were recruited by simple consecutive sampling.

All the patients were enquired for age, sex, and units of packed red blood cells (PRBCs) transfused till date. Serum ferritin levels were measured using enzyme-linked fluorescent assay by Biomerieux, India, and the values were recorded. Nine of the patients were found to be already receiving chelation therapy and rest 96 patients were not receiving any chelation therapy at the time of recruitment. They were also investigated with twodimensional (2D) echocardiography done by the consulting cardiologist in the Department of Cardiology, VIMSAR, Burla using the Philips hd11 model and the three different parameters, namely EF, left ventricular end diastolic diameter (LVEDD), and left ventricular end systolic diameter (LVESD) were noted for each of the patients and abnormal values were recorded using body surface area nomogram [14].

All the data were compiled in Microsoft Excel and statistical analysis was done as discussed in the following section. In this study, serum ferritin values, units of PRBCs transfused, age, and gender were analyzed for association with EF, LVEDD,
LVESD, individually using correlation-regression statistics to establish their predictive role in detecting abnormality in the echocardiographic variables through SPSS software version 25.

\section{RESULTS}

Out of 105 children, 55 were boys and 50 were girls with a mean age of $9.4 \pm 3.2$ years and a mean serum ferritin level of $3240 \pm 1254 \mathrm{ng} /$ $\mathrm{ml}$ and mean hemoglobin levels of $6.1 \pm 1.2 \mathrm{~g} / \mathrm{dl}$. With the regression-correlation statistics as evident from the correlationregression graphs, serum ferritin has a strongly negative correlation with LVEDD with Pearson's coefficient (r) being -0.511 with $\mathrm{p}=0.000$ (Fig. 1 ).

Serum ferritin has strongest negative correlation with $\mathrm{EF}$ $(\mathrm{r}=-0.604, \mathrm{p}=0.000)$ (Fig. 2).

Serum ferritin has weak positive correlation with LVESD $(r=0.084, p=0.393)$ (Fig. 3). Number of PRBCs transfused has strongly negative correlation with $\mathrm{EF}(\mathrm{r}=-0.785, \mathrm{p}=0.000)$ (Fig. 4), weak negative correlation with LVEDD ( $\mathrm{r}=0.297$, $\mathrm{p}=0.005$ ) (Fig. 4), and weak positive correlation with LVESD $(\mathrm{r}=0.413, \mathrm{p}=0.000)$ (Fig. 5).

The prediction model was further evaluated using the logistic regression equations as follows; cardiac iron overload $=1.324$ (age in years) +0.046 (sex of the child) -0.164 (units of PRBC) +0.003 (serum ferritin in $\mathrm{ng} / \mathrm{ml}$ ) -0.571

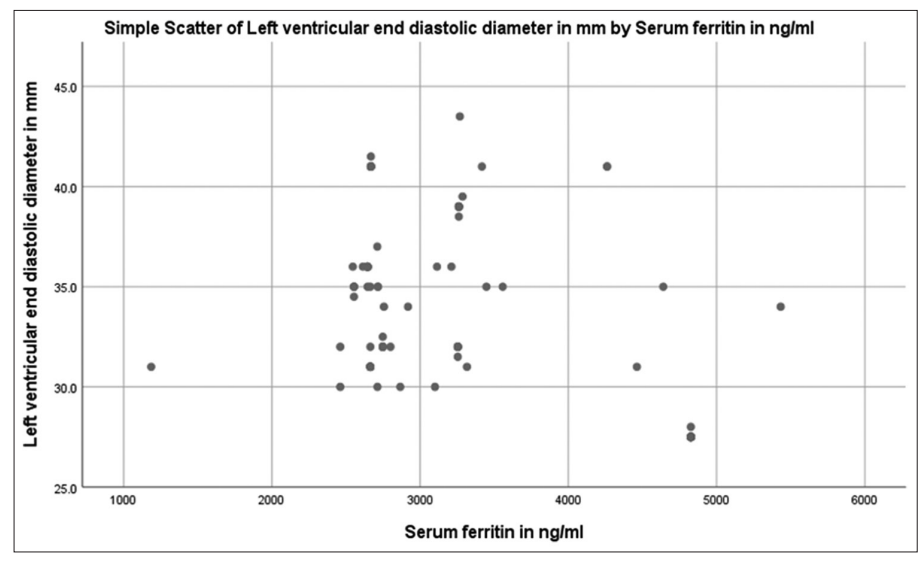

Figure 1: Correlation between left ventricular end-diastolic diameter and serum ferritin

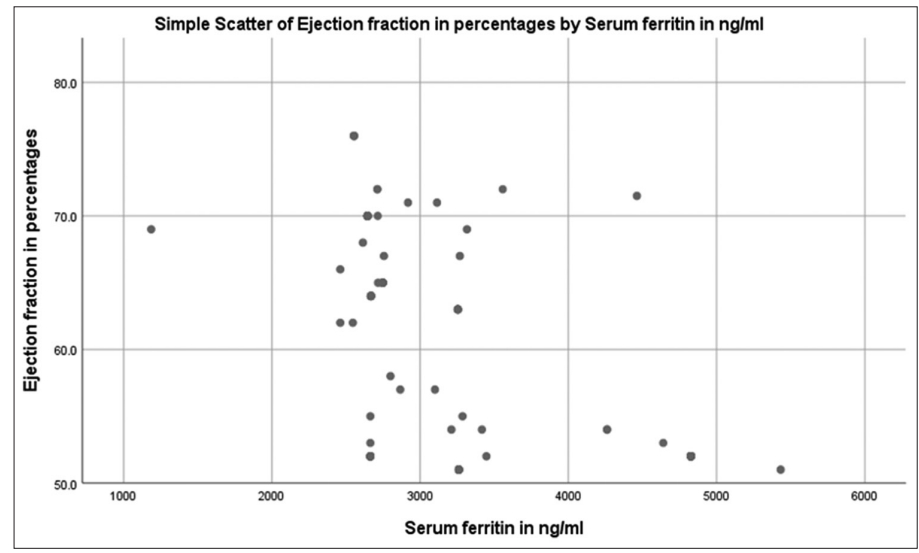

Figure 2: Correlation between ejection fraction and serum ferritin 


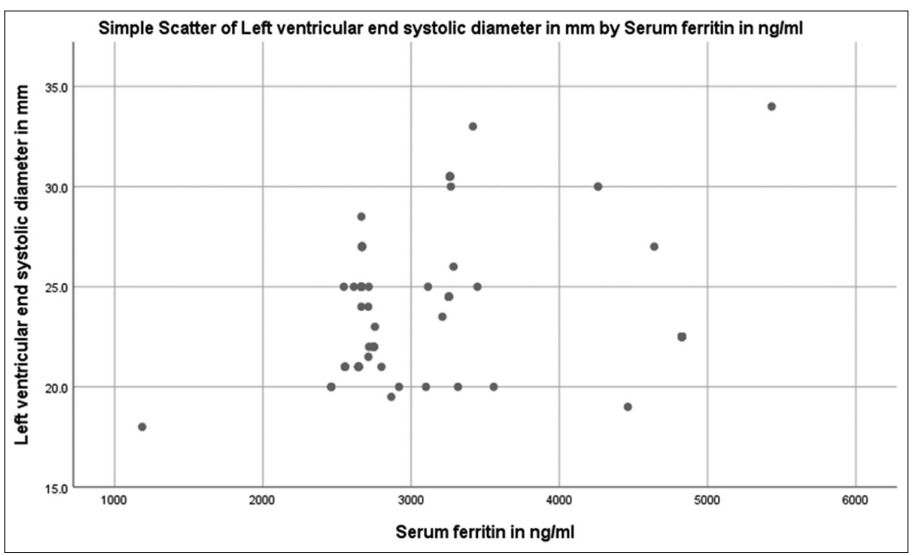

Figure 3: Correlation between left ventricular end-systolic diameter and serum ferritin

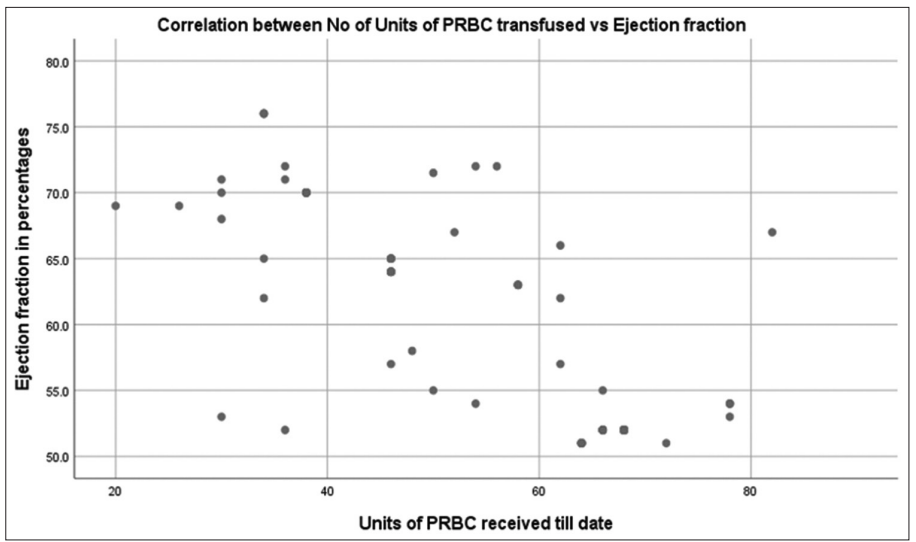

Figure 4: Correlation between ejection fraction and units of packed red blood cells transfused

(LVEDD in mm) +1.150 (LVESD in $\mathrm{mm}$ ) -0.096 (weight in $\mathrm{kg}$ ) +0.006 (height of the child in $\mathrm{cm}$ ) -21.467 .

The correlation between LVESD and units of PRBC transfused is described in Fig. 6. The mentioned model (Table 1) is good to fit, as evidenced by Cox and Snell R-Square of 0.747 and Nagelkerke R-Square $=1.000$ was obtained. This model fits the data aptly as Hosmer-Lemeshow $\chi^{2}$ test $(5)=0.000, p=1.000$. With this model, the probability of correct prediction is $93.7 \%$.

Still, some of the variables were insignificant in detecting cardiac iron overload; hence, they were excluded from the regression model, and new corrected regression model was formulated (Table 2). This new model is good to fit, as evidenced by Cox and Snell R-Square of 0.613 and Nagelkerke $\mathrm{R}$-Square $=0.821$ were obtained. This model fits the data aptly as the Hosmer-Lemeshow $\chi^{2}$ test $(8)=20.542(8), p=0.905$. With this model, the probability of correct prediction is $94.3 \%$, which was calculated in the new corrected logistic regression equation, i.e. cardiac iron overload $=1.997$ (age in years) -3.119 (sex of the child) -0.078 (units of PRBC) +0.003 (serum ferritin in $\mathrm{ng} / \mathrm{ml}$ ) -0.149 (LVEDD in $\mathrm{mm}$ ) -0.235 (weight in $\mathrm{kg}$ ) -10.928 .

$\mathrm{p}=1 / 1+\mathrm{e}-([1.997$ (age in years) -3.119 (sex of the child)0.078 (units of PRBC) +0.003 (serum ferritin in $\mathrm{ng} / \mathrm{ml}$ ) -0.149 (LVEDD in mm) -0.235 (weight in $\mathrm{kg}$ )]-10.928), where $\mathrm{p}$ is the probability of cardiac iron overload in multi-transfused pediatric beta-thalassemia. If all the risk factors in the above equation

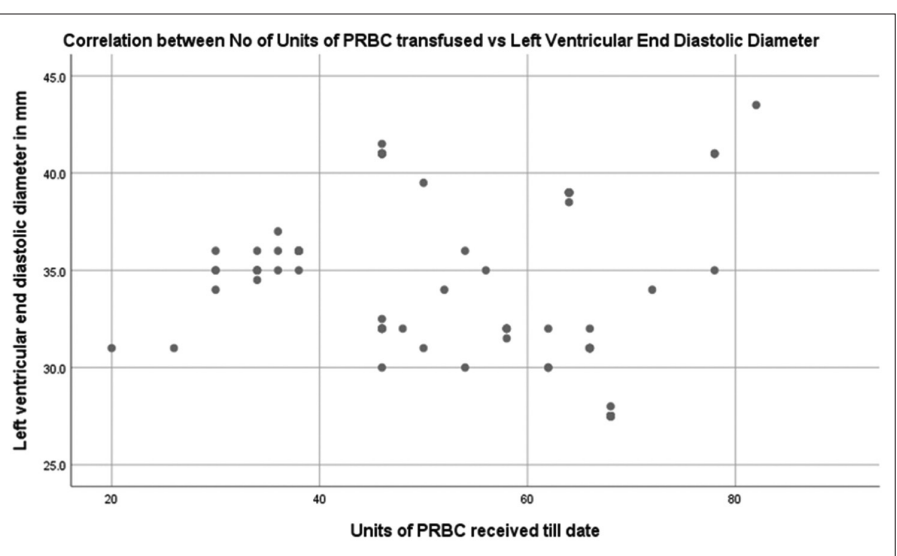

Figure 5: Correlation between left ventricular end diastolic diameter and units of packed red blood cells transfused

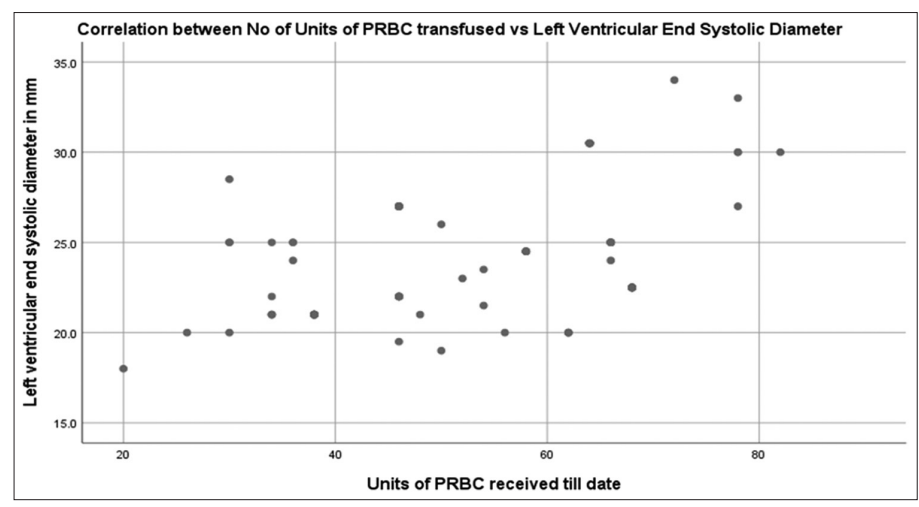

Figure 6: Correlation between left ventricular end-systolic diameter and units of packed red blood cells transfused

Table 1: Regression model for cardiac iron overload

\begin{tabular}{|c|c|c|}
\hline Risk factors & $\begin{array}{c}\text { Adjusted odds ratio } \\
(95 \% \mathrm{CI})\end{array}$ & p-value \\
\hline Age in years & $3.760(0.355-19.789)$ & 0.071 \\
\hline Sex of the child (1) & $1.048(0.020-15.133)$ & 0.082 \\
\hline Units of $\mathrm{PRBC}$ received till date & $0.849(0.723-0.996)$ & $0.045^{*}$ \\
\hline Serum ferritin in $\mathrm{ng} / \mathrm{ml}$ & $1.003(1.001-1.006)$ & $0.014 *$ \\
\hline $\begin{array}{l}\text { Left ventricular end-diastolic } \\
\text { diameter in } \mathrm{mm}\end{array}$ & $0.565(0.351-0.911)$ & $0.019^{*}$ \\
\hline $\begin{array}{l}\text { Left ventricular end-systolic } \\
\text { diameter in } \mathrm{mm}\end{array}$ & $3.158(0.388-7.183)$ & 0.836 \\
\hline Weight of the child in $\mathrm{kg}$ & $0.908(0.635-1.298)$ & 0.097 \\
\hline Height of the child in $\mathrm{cm}$ & $1.006(0.776-1.303)$ & 0.965 \\
\hline Ejection fraction in percentage & $0.723(0.419-1.020)$ & 0.865 \\
\hline
\end{tabular}

Table 2: Corrected regression model for cardiac iron overload

\begin{tabular}{lcc}
\hline Risk factors & $\begin{array}{c}\text { Adjusted odds ratio } \\
(\mathbf{9 5 \%} \text { CI) }\end{array}$ & p-value \\
\hline Age in years & $7.369(2.358-23.023)$ & $0.001^{*}$ \\
Units of PRBC received till date & $0.0925(0.814-1.050)$ & $0.045^{*}$ \\
Serum ferritin in ng/ml & $1.003(1.001-1.005)$ & $0.004^{*}$ \\
Weight of the child in kg & $0.791(0.620-1.008)$ & $0.019^{*}$ \\
Sex of the child (male) & $0.044(0.002-0.909)$ & $0.043^{*}$ \\
Left ventricular end-diastolic & $0.862(0.666-1.115)$ & $0.047^{*}$ \\
diameter in mm & & \\
\hline *p $<0.05$ is considered as statistically significant, PRBC: Packed red blood cells &
\end{tabular}


are present in a particular patient of let say a thalassemic boy of 8 years old with weight of $18 \mathrm{~kg}$ who has received 50 units of PRBC till date with serum ferritin value being $4462 \mathrm{ng} /$ $\mathrm{ml}$ and on 2D echocardiography, LVEDD was found to be $31 \mathrm{~mm}$, the following results were obtained; $\mathrm{p}=1 / 1+\mathrm{e}-(1.997$ $\times 8-3.119 \times 1-0.078 \times 50+0.003 \times 4462-0.149 \times 31-0.235 \times$ $18-10.928)=1 / 1+\mathrm{e}-(2.566)=1 / 1.0768=92.87 \%$. So it means, this patient has that the probability of getting cardiac iron overload is $92.87 \%$ and not getting cardiac iron overload is $7.13 \%$.

\section{DISCUSSION}

Iron toxicity induced cardiomyopathy is the most crucial cause of mortality in beta-thalassemia major children. Serum ferritin is the most commonly used predictor of iron overload in thalassemia [15]. The serum ferritin level is a non-specific marker for iron overload and may elevate in many clinical conditions, including inflammation, liver disease, collagen tissue disease, and malignancy [16]. Moreover, a low serum ferritin level does not correlate to a decreased risk of iron-induced cardiomyopathy [6]. Still, much needs to be addressed as cardiomyopathy related deaths are more preventable than combatable.

Very few studies have been undertaken that necessitate a primarily preventive approach for morbidity regarding iron overload toxicity. In one study, no significant correlation was observed between serum ferritin, number of units of transfused PRBC or age or gender on any cardiac parameter [17]. In our present study, we attempted at establishing some predictors of iron overload in the form of cardiomyopathy in beta-thalassemia. In the correlation graphs and logistic-regression equations, we can infer that serum ferritin has got the best correlation with EF which is negative followed by LVEDD which is negative as well but no correlation with LVESD. Similarly, number of units of PRBC transfused has got the best correlation with EF, which is negative, followed by LVESD, which is positive, followed by LVEDD, which is weakly negative. Furthermore, in the logistic regression table, we noted that age, sex, weight of the child, serum ferritin, number of PRBC transfused, and LVEDD which is an echocardiographic parameter have the significant predictive ability in detecting cardiac iron overload and can be used collectively for detection of at-risk patients well before in lead time.

Limitation of our study is less sample size, study design and could not be generalized as ours is the hospital-based study. Hence, in future, a follow-up study is highly awaited for best possible evidence in detecting risk factors for cardiac iron overload among beta-thalassemic children.

\section{CONCLUSIONS}

In beta-thalassemia, cardiac dysfunction assessment through echocardiography provides an early window to scrutinize for any cardiac iron overload toxicity induced dysfunction. This study depicts the significance of serum ferritin, number of units of
PRBCs transfused, age, weight, gender, and LVEDD as having predictive ability. Serum ferritin and number of PRBC transfused have the strongest correlation with EF. This knowledge can establish a warning bell in scrutinizing at-risk patients for cardiac iron overload well before in lead time to reduce associated morbidity and mortality.

\section{REFERENCES}

1. Olivieri NF. The $\beta$-thalassemias. N Engl J Med 1999;341:99-109.

2. Modell B, Khan M, Darlison M. Survival in beta-thalassemia major Sin UK: Data from the UK thalassemia register. Lancet 2000;355:2051-2.

3. Li CK, Luk CW, Ling SC, Chik KW, Yuen HL, Li CK, et al. Morbidity and mortality patterns of thalassaemia major patients in Hong Kong: Retrospective study. Hong Kong Med J 2002;8:255-60.

4. Domellof M, Dewey KG, Lonnerdal B, Cohen RJ, Hernell O. The diagnostic criteria for iron deficiency in infants should be re-evaluated. J Nutr 2002;132:3680-6.

5. World Health Organization. Serum Ferritin Concentrations for the Assessment of Iron Status and Iron Deficiency in Populations. Vitamin and Mineral Nutrition Information System. Geneva: World Health Organization; 2011.

6. Anderson LJ, Holden S, Davis B, Prescott E, Charrier CC, Bunce NH, et al. Cardiovascular T2-star (T2*) magnetic resonance for the early diagnosis of myocardial iron overload. Eur Heart J 2001;22:2171-9.

7. Kirk P, Roughton M, Porter JB, Walker JM, Tanner MA, Patel J, et al. Cardiac T2* magnetic resonance for prediction of cardiac complications in thalassemia major. Circulation 2009;120:1961-8.

8. Olivieri NF, Nathan DG, MacMillan JH, Wayne AS, Liu PP, McGee A, et al. Survival in medically treated patients with homozygous beta-thalassemia. N Engl J Med 1994;331:574-8.

9. Shivanna NH, Murthy GR, Ambica, Munirathnam G. Cardiac abnormalities in children with thalassemia major: Correlation of echocardiographic parameters with serum ferritin levels. Int J Contemp Pediatr 2016;3:12-5.

10. Wahidiyat PA, Liauw F, Sekarsari D, Putriasih SA, Berdoukas V, Pennell DJ. Evaluation of cardiac and hepatic iron overload in thalassemia major patients with T2* magnetic resonance imaging. Hematology 2017;22:8501-7.

11. Wood JC. Cardiac iron across different transfusion-dependent diseases. Blood Rev 2008;22 Suppl 2:S14-21.

12. Engle MA, Erlandson M, Smith CH. Late cardiac complications of chronic, severe, refractory anaemia with hemochromatosis. Circulation 1964;30:698-705.

13. Debaun M, Frei-jones M, Vichinsky E. Thalassemia syndromes. In: Kliegman RM, Stanton BF, St Geme JW, Schor NF, Behrman RE, editors. Nelson Textbook of Paediatrics. 20 $0^{\text {th }}$ ed. New Delhi: Reed Elsevier India Pvt. Ltd.; 2016. p. 2351.

14. Park M, editor. Noninvasive Techniques. In: Pediatric Cardiology for Practitioners. $6^{\text {th }}$ ed. New Delhi: Elsevier India Pvt. Ltd.; 2014. p. 87.

15. Olivieri NF, Brittenhan GM, Matsui D, Berkovitch M, Blendis LM, Cameron RG, et al. Iron-chelation therapy with oral deferiprone in patients with thalassemia major. N Engl J Med 1995;332:918-22.

16. Piperno A. Classification and diagnosis of iron overload. Haematologica. 1998;83:447-55.

17. Tantiworawit A, Tapanya S, Phrommintikul A, Saekho S, Rattarittamrong E, Norasetthada L, et al. Prevalence and risk factors for cardiac iron overload and cardiovascular complications among patients with thalassemia in Northern Thailand. Southeast Asian J Trop Med Public Health 2016;47:1335-41.

Funding: None; Conflict of Interest: None Stated.

How to cite this article: Mishra NR, Biswal SS, Majhi SC. Predictors of iron overload toxicity in multi-transfused beta-thalassemic chiladren. Indian J Child Health. 2019; 6(7):341-344.

Doi: 10.32677/IJCH.2019.v06.i07.003 